\title{
An evaluation of the federal grazing fee formula
}

\author{
L. ALLEN TORELL, NEIL R. RIMBEY, LARRY W. VAN TASSELL, JOHN A. TANAKA, AND E. TOM \\ BARTLETT
}

Authors are Professor, Department of Agricultural Economics and Agricultural Business, New Mexico State University, Las Cruces, N. M. 88003; Professor, Department of Agricultural Economics and Rural Sociology, University of Idaho, Caldwell, Ida. 83605; Professor and Head, Department of Agricultural Economics and Rural Sociology, University of Idaho, Moscow, Ida., 83844; Associate Professor, Eastern Oregon Agricultural Research Center - Union Station, Union, Ore. 97883; and Professor Emeritus, Department of Rangeland Ecosystem Science, Fort Collins, Colo. 80523.

\begin{abstract}
The federal grazing fee is currently set using the Public Rangeland Improvement Act (PRIA) fee formula established in 1978 and modified in 1986 . The formula is adjusted annually using indices of private land grazing lease rates (Forage Value Index, FVI), prices received for beef cattle (Beef Cattle Price Index, BCPI), and costs of beef production (Prices Paid Index, PPI). The FVI tracks price movement in the private forage market and was the only index originally proposed to be included in the fee formula. Public land ranchers and the Interdepartmental Grazing Fee Technical Committee assigned to study grazing fee alternatives in the 1960s questioned the ability of the FVI to account for short-term demand, supply, and price equilibrium, and, for this reason, the BCPI and PPI were added to the fee formula. Nearly 40 years of data are now available to evaluate whether adding the BCPI and PPI did, in fact, help explain short-term market fluctuations. Analysis shows that if tracking the private forage market is the primary objective, the fee formula should have included only the FVI. Including the BCPI and the PPI has caused calculated grazing fees to fall further and further behind private land lease rates. Had the $\$ 1.23$ base fee in the PRIA formula been indexed by only the FVI, the federal grazing fee would have been $\$ 4.36 \mathrm{AUM}^{-1}$ instead of $\$ 1.43 \mathrm{AUM}^{-1}$ in 2002 . It is time to consider the feasibility of a competitive bid system for public lands, or, at the very least, drop the BCPI and PPI indices and adopt a new fee formula that generates more equitable grazing fees.
\end{abstract}

Key Words: grazing leases, forage value, public lands, public land grazing, grazing permits, Public Rangeland Improvement Act (PRIA)

A long and interesting history of conflict preceded implementation of the current federal grazing fee formula (USDI/USDA 1977, USDA/USDI 1986, 1992). Some of the major areas of contention included the amount charged, how grazing fees were to be adjusted through time, and whether fees should vary in different areas of the West. All of these issues were part of the debate when the Public Rangeland Improvement Act (PRIA) fee formula was adopted in the late 1970 s, and the debate continues.

A detailed historical review of grazing fee policy is provided by Backiel and Rogge (1985), while Dutton (1953) concentrated on grazing fee issues within the structure and history of the Forest

Manuscript accepted 15 Feb. 03.

\section{Resumen}

El pago de pastoreo federal es actualmente determinado usando la fórmula de pago del Acta de Mejoramiento de Pastizales Públicos (AMPP) establecida en 1978 y modificada en 1986. La fórmula es ajustada anualmente usando índices de tasas de arrendamiento de pastizales privados (Índice de Valor Forrajero, IVF), precios recibidos para ganado de carne (Índice de Precios de Ganado de Carne, IPGC), y costos de producción de la carne (Índice de Precios Pagados, IPP). El IVF monitorea el movimiento de precio del forraje en el mercado privado y fue el único índice originalmente propuesto para ser incluido en la fórmula de pago. Rancheros de tierras públicas y un Comité Técnico de Pago de Pastoreo asignado para estudiar alternativas en el pago de pastoreo en los 1960s, cuestionaron la habilidad del IVF para contabilizar por la demanda de corto plazo, oferta, y equilibrio del precio, y por esta razón el IPGC y el IPP fueron agregados a la fórmula de pago. Cerca de 30 años de datos están ahora disponibles para evaluar si el agregar el IPGC y el IPP en efecto ayudó a explicar las fluctuaciones del mercado en el corto plazo. Análisis muestran que si monitorear el mercado privado de forraje es el objetivo primario, entonces la fórmula de pago debería haber incluido solamente el IVF. La inclusión del IPGC, y especialmente del IPP, ha causado que los precios de pastoreo calculado caigan cada vez más por debajo de las tasas de arrendamiento de tierras privadas. Si el pago base de $\$ 1.23$ dólares en la fórmula de la AMPP fuera indexado solamente por el IVF, el pago de pastoreo federal hubiera sido $\$ 4.36 \mathrm{UAM}^{-1}$, en vez de $\$ 1.43 \mathrm{UAM}^{-1}$ en el 2002. Es tiempo de considerar la factibilidad de un sistema competitivo de licitamiento para tierras federales, o al menos adoptar una nueva fórmula de pago que genere pagos de pastoreo más equitativos, y destilar los índices de IPGC y IPP.

Service. Table 1 briefly reviews what we feel are the key policy decisions and legislation surrounding the grazing fee issue. This historical progression covers the time from the inception of the Forest Service in 1906 through the passage of PRIA in 1978 and subsequent formula modifications after a 1986 Executive Order (EO) was signed by President Reagan. The political negotiation, debate, and legislation, as detailed, resulted in the PRIA fee formula that is used to set grazing fees on Bureau of Land Management (BLM) and Forest Service (FS) lands today. Recognizing this history is important for assessing whether PRIA has met the objectives of Congress and others that proposed and adopted the fee formula.

In this paper, we review the relevant history and legislation associated with the PRIA fee formula. We discuss the original fee 
Table 1. An abbreviated history of grazing fees and the PRIA fee formula.

\begin{tabular}{ll}
\hline \hline Grazing Fee Study and Legislation & Description \\
\hline 1906 Forest Service Fees Implemented & Forest Service fees were imposed on ranchers and settlers accustomed to free and unrestricted \\
grazing use. Average fees were about $\$ 0.05$ AUM $^{-1}$ (Dutton 1953, USDI/USDA 1977, p. 2-4).
\end{tabular}

1916 Comparable Forest Service Lease Rate Study

In 1916 the U.S. Forest Service attempted to determine fair compensation for national-forest range by studying the rental value of 900 tracts of private land similar to U.S. Forest Service ranges (Dutton 1953).

1924 Rachford Appraisal

Based largely on an appraisal of supposedly comparable privately owned land (Rachford 1924) and the recommendation of Dan Casement, a Kansas livestock producer assigned by the Secretary of Agriculture to review the appraisal, variable fees and the practice of basing fees on the price of beef and lamb was adopted and prevailed in the FS from 1928 until the mid-1960s (Backiel and Rogge 1985, USDI/USDA 1977, p. 2-2). After passage of the Taylor Grazing Act in 1934, the Grazing Service began charging a $\$ 0.05 \mathrm{AUM}^{-1}$ fee on BLM land in 1936. This fee had no specific economic rationale except to cover administrative costs of the land agencies and was a politically negotiated compromise (USDI/USDA 1977, p. 2-3).

1966 Grazing Cost Study

In 1959-1960, an Interdepartmental Task Force was formed to undertake a joint grazing fee study that would be used to develop a uniform approach to grazing fees between the federal land agencies. One of the major responsibilities of the task force was the 1966 Western Livestock Grazing Survey that provided a total grazing cost comparison of nearly 10,000 public land permittees and private land forage lessors. This total cost comparison indicated that, if interest on the permit investment was excluded (which was controversial), a weighted average base grazing fee of $\$ 1.23 \mathrm{AUM}^{-1}$ would make total grazing costs on public and private lands equal. This base rate was a weighted average for both BLM and FS lands, and for cattle and sheep operations (USDI/USDA 1977, p. 2-22). Because total grazing costs were as variable within ranching areas of the West as they were between areas, no statistical basis could be found for differentiating fees between grazing districts or areas (Arthur D. Little 1967, 1968).The weighted average \$1.23 $\mathrm{AUM}^{-1}$ cost differential became the base value used in PRIA. Further, the task force proposed to adjust the base fee annually by an index of private grazing land lease rates, the Forage Value Index, or FVI (Backiel and Rogge 1985).

1969 Grazing Fee Proposal

In 1969, a new fee schedule for FS and BLM lands was announced that adapted the proposed fee increases to the $\$ 1.23 \mathrm{AUM}^{-1}$ base rate (USDI/USDA 1977, p. 2-27). The 1969 fee schedule and formula would use the FVI to adjust fees through time. Implementation of the 1969 fee schedule proceeded with controversy and various legal delays and fee moratoriums.

1973 American National Cattlemen's Association proposal

In October 1973, the American National Cattlemen's Association (now the National Cattlemen's Beef Association, NCBA) proposed a new fee formula to the Secretaries of Interior and Agriculture that would use indices of beef prices and prices paid to adjust grazing fees. The 19641968 period would serve as the base period for both indices, and, as noted by Backiel and Rogge (1985), the new formula would have shifted the basis for fee adjustment from a private land lease rate equivalency, based on the FVI, to an ability-to-pay basis using the Beef Cattle Price Index (BCPI) and Prices Paid Index (PPI). The new formula was not accepted by the land agencies.

1976 Federal Land Policy and Management Act

The 1976 Federal Land Policy and Management Act (FLPMA) set out major, overall public land management and policy objectives and mandated that a grazing fee study be submitted to Congress within one year. The resulting 1977 Grazing Fee Study evaluated seven alternative procedures for determining grazing fees, including the fee formula proposed by the NCBA and another formula, which eventually became PRIA, proposed by a Technical Committee assigned to review public land grazing fees by the Senate Interior and Insular Affairs committees (USDI/USDA 1977). The technical committee fee formula was supported by livestock interests because, similar to their own proposal, it included livestock prices and production costs as adjustment factors. Inclusion of these price and cost factors was of primary concern to livestock interests and they maintained that severe hardships to thousands of individual ranchers could be avoided by including these indices in the fee formula (Backiel and Rogge 1985, p. 28).

The Grazing Fee Technical Committee argued that the FVI would adequately measure the longterm trend grazing fee and forage values. However, they questioned the ability of the index to capture short-term instabilities that result during periods of disequilibrium (USDI/USDA 1977, p. 3-34). They suggested that, by adding the BCPI and PPI, the fee formula would be better able to account for short-term fluctuations in forage demand and supply. It also provided a compromise between the land agencies that wanted to use only the FVI and public land ranchers who wanted to use only the BCPI and PPI. Including all three indices was criticized because beef prices and production costs should already be included when ranchers formulate lease bids based on livestock production value. Research has since shown this to be the case (Van Tassell and McNeley 1997, McCarl and Brokken 1985). 

were set using the new PRIA fee formula in 1979. Using the PRIA formula, grazing fees increased in both 1979 and 1980. In both years, the 25-percent limit of change that was included in the legislation kept fees below the calculated value. The $\$ 2.36 \mathrm{AUM}^{-1}$ fee in 1980 was the highest fee ever reached, and PRIA-generated fees have trended downwards ever since.

The PRIA fee formula is calculated as $\mathrm{Fee}_{\mathrm{t}}=\$ 1.23 \times \frac{\left(\mathrm{FVI}_{\mathrm{t}-1}+\mathrm{BCPI}_{\mathrm{t}-1}-\mathrm{PPI}_{\mathrm{t}-1}\right)}{100}$ The data used

to estimate the indices are described in detail in USDI/USDA (1977) and USDA/USDI (1992). Kearl (1989) provides a critical review of the data collection procedures and the index components. Historical values for the indices are provided in Appendix A.

1986 Executive Order 12548

The PRIA fee formula expired on December 31, 1985, but was indefinitely extended by Executive Order $12548(2 / 14 / 86)$ with an imposed minimum fee of $\$ 1.35 \mathrm{AUM}^{-1}$. The Executive Order also included a provision that changed the data series used to compute the FVI from a $\$ \mathrm{AUM}^{-1}$ to a $\$$ head $^{-1}$ basis. We understand that this change occurred not because of a perceived need for a different data series, but rather the loose language used in the Executive Order, i.e. those writing the order did not recognize that $\$$ head ${ }^{-1}$ and $\$ \mathrm{AUM}^{-1}$ values are not the same and specified $\$$ head $^{-1}$ instead of the $\$ A U M^{-1}$ index that had historically been used (Personal communication, Mr. Don Waite, former BLM economist, Washington, D.C.). The changes proposed in the Executive Order were implemented with the 1986 fee year.

proposal supported by the BLM and FS that precluded the Beef Cattle Price Index (BCPI) and Prices Paid Index (PPI), and then evaluate whether the addition of these 2 "ability-to-pay" indices help track and explain the movement of grazing lease rates over time, as was originally projected. Similar studies conducted 15 years ago also evaluated the validity of including the ability-to-pay indices in the PRIA fee formula (Brokken and McCarl 1987, McCarl and Brokken 1985). This study provides an update of the analysis and demonstrates the continued problems that adding these indices to the fee formula have created. Finally, we review the policy implications and alternatives available for setting grazing fees on public lands in the future.

\section{Methods}

Nearly 40 years of data are available to evaluate whether adding the Beef Cattle Price Index (BCPI) and Prices Paid Index (PPI) to the PRIA fee formula improved the formula's predictive ability as envisioned by a 1977 Grazing Fee Technical Committee. However, changes in data collection and policies have altered how PRIA-generated fees are computed. The data used to compute the Forage Value Index (FVI) was redefined with a 1986 Executive Order (EO) issued by President Ronald Reagan (Table 1). The Executive Order further directed that a minimum fee of $\$ 1.35 \mathrm{AUM}^{-1}$ would be charged under the PRIA fee formula. Only the first change, the redefinition of the FVI index from a $\$ \mathrm{AUM}^{-1}$ to $\$$ head $^{-1}$ was consid- ered in this analysis. The analysis considers grazing fees that would be generated by the unrestricted Public Rangeland Improvement Act (PRIA) formula, ignoring the grazing fee floor set by EO 12548. Additional regressions were done to determine whether results were different when the FVI was calculated on an AUM basis (FVIAUM in Appendix A), as originally structured.

The analysis is conducted with recognition that the data used to compute PRIA indices has been criticized on numerous accounts. Major criticisms include: a relatively small amount of data is collected to represent all of the western states; the FVI is based on hearsay as people are asked to recall or speculate on lease rates in the area; the BCPI is computed for cattle weighing over $227 \mathrm{~kg}$ (500 lbs) and does not include the lighter feeder calves produced on many western ranches; and the PPI excludes major feed expenses for western ranches. Kearl (1989), Brokken and McCarl (1987) and USDA/USDI (1986, 1992) provided additional detail about these and other criticisms and evaluated ways the indices could be changed and improved.

We start with the earlier statistical model defined by McCarl and Brokken (1985):

$\mathrm{FVI}_{\mathrm{t}+1}=\beta_{0}+\beta_{1} \mathrm{FVI}_{\mathrm{t}}+\beta_{2} \mathrm{BCPI}_{\mathrm{t}}+\beta_{3}$ $\mathrm{PPI}_{\mathrm{t}}+\mathrm{u}_{\mathrm{t}}$.

The beta coefficients are estimated regression parameters. Using this regression equation an estimate of the private land lease rate index during the next period $\left(\mathrm{FVI}_{\mathrm{t}+1}\right)$ based on indexed values of private land lease rates, beef prices, and pro- duction costs during the current period can be made. As noted by McCarl and Brokken (1985, p. 775), the regression of current and lagged values is based on a normalization (indexing) of private land lease rate data. Predicting lease rates at year $\mathrm{t}+1$ is equivalent to predicting $\mathrm{FVI}_{\mathrm{t}+1}$ with normalization of the data. The error term $\left(u_{t}\right)$ captures random differences in the FVI between years.

Dividing the predicted $\mathrm{FVI}_{\mathrm{t}+1}$ (from equation 1) by 100 and multiplying by the 1964-1968 base lease rate used to estimate the FVI index $\left(\$ 3.65 \mathrm{AUM}^{-1}\right)$ gives the estimated private land lease rate at time $t+1$. Similarly, because public land grazing fees should be less than private land lease rates when higher non-fee grazing costs for public lands are considered, equation 1 tracks public land grazing fees when the base fee rate is reduced. Multiplying by the $\$ 1.23 \mathrm{AUM}^{-1}$ Public Rangeland Improvement Act (PRIA) base (Table 1), for example, provides a grazing fee estimate during year $t+1$ when the beta coefficients of equation 1 are not restricted. The PRIA formula implies the restrictions $\beta_{0}=0, \beta_{1}=1, \beta_{2}=1$, and $\beta_{3}$ $=-1$.

Several alternative statistical results are possible if the beta coefficients in equation 1 are varied and estimated using regression techniques. First, it may be that an equal unitary weighting should not be attached to each index, but with all 3 indices statistically important in predicting forage value. Second, the appropriate weighting for any particular index may not be statistically different from 1 and some indices may be statistically insignificant. As noted by Brokken and McCarl (1987, 
p. 63), justification for PRIA would be evident if the implied restrictions of PRIA are not statistically significant (i.e., imposing the above restrictions does not significantly decrease the explanatory power of the model as measured by $\mathrm{R}^{2}$ ).

The statistical significance of the PRIA restrictions was tested using restricted least squares regression. Using the residual sum of squares from the restricted (RSSR) and unrestricted ( RSS $_{\mathrm{UR}}$ ) models, the appropriate test statistic is given by an F-distribution with $\mathrm{m}$ and $\mathrm{n}-\mathrm{k}$ degrees of freedom. The test statistic can also be formulated in terms of model $\mathrm{R}^{2}$ values. The number of restrictions imposed, the number of observations and the number of parameters estimated in the unrestricted model are denoted by $\mathrm{m}, \mathrm{n}$, and $\mathrm{k}$, respectively. The appropriate F-statistic can be computed as follows (Greene 1993):

$$
\mathrm{F}=\frac{\left(\mathrm{RSS}_{\mathrm{R}}-\mathrm{RSS}_{\mathrm{UR}}\right) / \mathrm{m}}{\mathrm{RSS}_{\mathrm{UR}} /(\mathrm{n}-\mathrm{k})} \text { or } \frac{\left(\mathrm{R}_{\mathrm{UR}}^{2}-\mathrm{R}_{\mathrm{R}}^{2}\right) / \mathrm{m}}{\left.\mathrm{R}_{\mathrm{UR}}^{2} / \mathrm{n}-\mathrm{k}\right) .}
$$

Statistical significance of the F-statistic would suggest that at least 1 of the imposed model restrictions does not hold.

Using data defining annual values of the PRIA indices (Appendix A), equation 1 was first estimated with no restrictions imposed on the beta coefficients. This unrestricted model resulted in equations similar to those estimated by McCarl and Brokken (1985), Torell et al. (1989), Rimbey (1990), and Bartlett et al. (1993) to evaluate what parameter weighting should be attached to the PRIA indices to best predict forage value on a West-wide and state-level basis. These unrestricted regressions are now used to index state land grazing fees in Idaho and $\mathrm{New}$ Mexico (Rimbey 1990, Torell et al. 1989).

To test various restrictions on the estimated parameters, additional restricted models were evaluated using the TEST statement within PROC REG of SAS (Freund and Littell 1991). The first set of restrictions tested were that PRIA is an appropriate model formulation, or the null hypothesis of the first test, $\mathrm{H}_{0}: \beta_{0}=0, \beta_{1}$ $=1, \beta_{2}=1$, and $\beta_{3}=-1$. A second test specified $\mathrm{H}_{0}$ as $\beta_{1}=1, \beta_{2}=0$, and $\beta_{3}=0$ and was used to test whether the BCPI and PPI jointly added explanatory power to the model. This further tested whether only the lagged FVI variable should be used to predict FVI during the current period, similar to the original fee adopted in 1969 (USDI/USDA 1977).

\section{Results}

Using data from 1964-2001, the unrestricted Public Rangeland Improvement Act (PRIA) equation was estimated to be:

$$
\begin{aligned}
& F \hat{V} I_{t}=4.5561+0.906 * \mathrm{FVI}_{\mathrm{t}-1} \\
& +0.085 \mathrm{BCPI}_{\mathrm{t}-1}+0.0085 \mathrm{PPI}_{\mathrm{t}-1} \\
& (0.0476) \quad(0.08475)
\end{aligned}
$$

$\mathrm{R}^{2}=0.985, \overline{\mathrm{R}}^{2}=0.984, \mathrm{n}=37$.

The standard error of the estimate is in parentheses, with $*$ signifying that the estimated parameter is individually statistically significant at the $\alpha=0.05$ level. Only the lagged Forage Value Index (FVI) is statistically significant in the equation.

Durbin's $h$ statistic was estimated to be -11.28 , indicating autocorrelation $(\mathrm{P}<$ 0.001 ). White's test for heteroscedasticity did not indicate a significant problem $(\mathrm{P}<$ $0.086)$. Multicollinearity was a problem in the model. Data for the FVI, Prices Paid Index (PPI), and Beef Cattle Price Index (BCPI) variables were highly correlated ( $\mathrm{r}$ $>0.90$ ), which was not an unexpected result. As noted by McCarl and Brokken (1985), the FVI conceptually includes the other 2 variables because lessors of forage should consider livestock prices and production costs when formulating forage lease prices.

Testing the restrictions imposed by PRIA, using equation 2, resulted in a highly significant $\mathrm{F}$-statistic $(\mathrm{F}=1,526, \mathrm{P}<$ $0.0001)$. This suggests that at least one of the restrictions implied by PRIA does not hold. The second test, $\mathrm{H}_{0}: \beta_{1}=1, \beta_{2}=0$, and $\beta_{3}=0$, resulted in an insignificant $F$ statistic $(F=1.17, P<0.34)$, suggesting that the PRIA restrictions that did not hold in the first test were the inclusion of the BCPI and PPI.

The equation suggested by the second statistical test is not exactly equal to the 1969 fee formula (i.e., $\mathrm{FVI}_{\mathrm{t}}=1 \times \mathrm{FVI}_{\mathrm{t}-1}$ ). Rather, the equation includes a statistically insignificant intercept:

$$
\mathrm{FVI}_{\mathrm{t}}=\underset{(4.88)}{6.6361}+\underset{(0.022)}{1.00 \mathrm{FVI}_{\mathrm{t}-1}}
$$

$\mathrm{R}^{2}=0.984,=\overline{\mathrm{R}}^{2}=0.983$

Additional restricted least squares analysis indicated that if the second test is modified to $\mathrm{H}_{0}: \beta_{0}=0, \beta_{2}=0$, and $\beta_{3}=0$, such that the intercept is forced to 0 and the slope coefficient on lagged FVI is not fixed at 1 , then the estimated slope coefficient for $\beta_{1}$ is 1.0285 , and this slope coefficient is statistically different from one $(\mathrm{F}$ $=1.82, \mathrm{P}<0.16)$. This suggests that the nominal FVI grew by $2.85 \%$ per year over the study period ${ }^{1}$, and should be considered when predicting annual changes in forage value:

$$
\mathrm{FVI}_{\mathrm{t}}=\underset{(0.0075)}{1.0285 \times \mathrm{FVI}_{\mathrm{t}-1}}
$$

$\mathrm{R}^{2}=0.998$, but redefined when forced through the origin

The results did not change when the AUM definition contained in the Executive Order (EO) was used to calculate FVI for all years (Appendix A). Conclusions of all statistical tests were identical. The estimated beta coefficients were slightly different, but statistically unchanged. The slope coefficient of equation 5, for example, increased to 1.0286 while the intercept term in equation 4 changed to 6.391. Similarly, the conclusions of the statistical tests and implications of the analysis remain unchanged relative to the earlier findings of McCarl and Brokken (1985).

\section{Discussion}

Adding the Beef Cattle Price Index (BCPI) and Prices Paid Index (PPI) to the Public Rangeland Improvement Act (PRIA) formula did not improve the fee formula's ability to predict annual forage values. In fact, adding these 2 indices ruined the predictive ability of the formula and PRIA-generated grazing fees have fallen further and further behind private land lease rates through time (Fig. 1). Similar to the earlier findings of McCarl and Brokken (1985), our results show that these 2 indices did not improve the ability of the fee formula to predict forage value and did not help explain short-term market imperfections as envisioned by the 1977 Grazing Fee Technical Committee. Including these 2 indices in the PRIA formula, especially with a weighting of 1 , was a mistake if predictive power and tracking of the private forage market are important. Using a unitary weighting, while intuitive in a practical sense, does not give the correct coefficient in a statistical sense. The 1977 Grazing Fee Study stated that a desirable fee formula should prevent future discrepancies and adjust so that fair market value is charged in future years as well as the present (USDI/USDA 1977, p. 1-8). By this standard the PRIA formula has not been a desirable fee formula.

Had only the Forage Value Index (FVI) been used to adjust grazing fees (the 1969 fee formula), the federal grazing fee would have been $\$ 4.15 \mathrm{AUM}^{-1}$ during the 2002 grazing season. If equation 5 had been 
used, whereby growth in the FVI is recognized and expected, the 2002 fee would have been $\$ 4.36 \mathrm{AUM}^{-1}$ (Fig. 1). Fair market value of public land forage was estimated to be about $1 / 3$ the private land lease rate (PLLR) during the 1964-1968 base period of PRIA $\left(\$ 1.23 \mathrm{AUM}^{-1} \div \$ 3.65\right.$ $\left.\mathrm{AUM}^{-1}=0.337\right)$. The $\$ 4.36 \mathrm{AUM}^{-1}$ fee obtained from equation 5 would represent nearly the same ratio of value in 2002 $\left(\$ 4.36 \mathrm{AUM}^{-1} \div \$ 12.30 \mathrm{AUM}^{-1}\right.$ average 2002 PLLR $=0.354$ ). The fee would now be in the $\$ 3$ to $\$ 5 \mathrm{AUM}^{-1}$ range that was estimated to be "fair market value" during 1992 as part of a Grazing Fee Task Group assigned to advise BLM and FS on grazing fees (Bartlett et al. 1993). But, even with adjustment in the updating mechanism of the fee formula, value estimates for public land forage will remain controversial. There is no general agreement about the comparability of private and public land forage, nor is there agreement about what allowances and deductions should be credited to compensate for differences in forage quality, location, investments, and non-fee grazing costs (Kearl 1989).

On the criterion of equity, the PRIA fee formula has been increasingly beneficial to public land ranchers if the historical precedent of not including interest on the grazing permit investment as a grazing cost is continued (USDI/USDA 1977, p. 3-8). It has been unfair to livestock producers that do not hold public land grazing permits, when judged against the criterion that an equitable fee should charge a similar amount as if the resource was used privately (USDI/USDA 1977, p. 1-8). If PRIA continues on the same general trend (Fig. 1), it is likely that the federal grazing fee will continue to be primarily determined by the $\$ 1.35 \mathrm{AUM}^{-1}$ floor set by Executive Order 12548, as it was for the 1995 through 2001 fee years.

One can only speculate about why the PRIA grazing fee formula has persisted for over 20 years. Economists pointed out problems of double counting with the formula even before it was implemented (Backiel and Rogge 1985). The poor tracking ability of the formula was identified before PRIA expired in 1985 (McCarl and Brokken 1985). Yet, the PRIA fee formula with Executive Order modification continues.

According to Darwin Nielsen, an agri-

\footnotetext{
${ }^{\mathrm{I}}$ Over the same study period the rate of inflation averaged $4.8 \%$ and average lease rates fell in real terms. McCarl and Brokken (1985) reported a similar regression coefficient for the earlier 1964-1983 period.
}

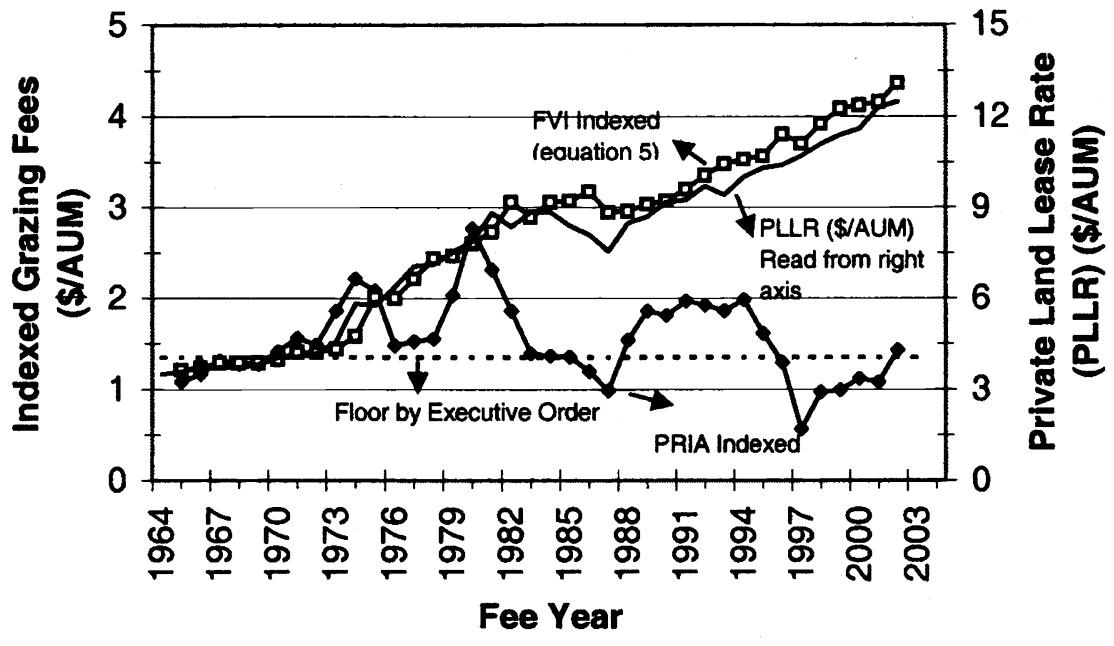

Fig. 1. Private land lease rates $\left(\$ \mathrm{AUM}^{-1}\right)$ compared with indexed grazing fees computed using the unrestricted Public Rangeland Improvement Act (PRIA) index and the Forage Value Index (FVI) from equation 5.

cultural economist actively involved with the grazing fee discussions as PRIA was adopted, political influence and pressure from public land ranchers played a significant role in the decision to include the BCPI and PPI in the PRIA fee formula (personal communication, Darwin B. Nielsen, Utah State University, retired, 10 October, 2000). Public land ranchers have actively lobbied to maintain the fee formula and perhaps the persistence of the formula can be attributed to their continued political activity and support.

Numerous grazing fee proposals have surfaced since the PRIA formula expiration date in 1985, including fee proposals studied in 1986 and updated in 1992 (USDA/USDI 1986, 1992). This was followed by the Incentive-Based Grazing Fee System in 1993 (USDI/USDA 1993), which was a study of grazing costs in Idaho, New Mexico, and Wyoming.

The Incentive-Based Fee Study was completed just as the Clinton administration came to Washington, D.C. The new administration started with an enthusiasm and desire to do something positive for the environment. Public lands were perceived to be in bad shape (USDI/USDA 1994, p. 5) and the new administration planned to reform grazing and mining regulations, and moved in a new direction that was called Rangeland Reform '94. Grazing fees and alternatives to improve rangeland health were considered in the draft Environmental Impact Statement (EIS) document (USDI/USDA 1994), but the focus eventually moved to rangeland health and fee reform was eliminated.

Grazing fee and management alternatives proposed in Rangeland Reform '94 were extremely controversial. The BLM and FS received over 20,000 comments to the draft EIS (USDI/USDA 1995). Efforts to change grazing fee policy under Rangeland Reform '94 were never completed. According to Lee Oteni, special assistant to the BLM Director and project leader for Rangeland Reform '94, BLM did not believe pursuing Rangeland Reform '94 management initiatives and increasing the grazing fee would be worth the necessary political capital (personal communication, 25 October, 2000).

\section{Policy Implications and Alternatives}

Differences in private land lease rates between states and regions (Tittman and Brownell 1984, Van Tassell and McNeley 1997, LaFrance and Watts 1995) and the widening difference between lease rates and public land grazing fees generated by using the PRIA grazing fee formula, have led researchers and policy analysts to different conclusions about how grazing fee policy should proceed. Nielsen (1972, p. $6)$ suggested that a competitive bid system would come closest to collecting full market value. Gardner (1963, 1983, 1989, 1997) argued that permittees should be given permanent rights to their grazing allotments. They should then be allowed to sell those rights to the highest bidder without restriction. He proposed that this disposal program might start with long-term competitive leases on an experimental basis and felt that the eventual privatization of the public lands would improve the efficiency of resource allocation (Gardner 
1983, p. 227). Similarly, LaFrance and Watts (1995) concluded public lands should be permanently transferred to the private sector. Whittlesey et al. (1993) would base grazing fees on the public cost of providing grazing in a multiple use framework. Fees would differ by grazing unit as acceptable stocking rates, grazing practices, and administrative costs vary.

While no uniform grazing fee recommendation has been made, perhaps a uniform message from this and previous research does emerge - the current PRIAgenerated fee is inadequate. The fee formula has not met the objective of adjusting grazing fees through time so as to charge fair market value in current and future years (USDI/USDA 1977, p. 1-8). A growing disparity has arisen between private land lease rates and the public land grazing fee.

The \$1.35 $\mathrm{AUM}^{-1}$ grazing fee floor is where PRIA-generated grazing fees will likely remain in the future. It is a minimal grazing fee. But, there is no evidence that public land ranchers are subsidized and make an inflated rate of return because of low grazing fees. As noted by Martin and Jeffries (1966), Pope and Goodwin (1984), Workman (1988), Torell and Bailey (2000) and Bartlett et al. (2002), ranch properties are overpriced relative to their livestock earning potential. Private and public land ranchers have paid too much for western ranches and grazing permits based on the value of livestock production. At current grazing fee rates, or even with no grazing fees, public land ranchers will continue to make a rate of return below what could be made from alternative investments of similar risk (Torell and Bailey 2000, Torell et al. 2001, Bartlett et al. 2002). Inflated ranch prices and grazing permit investments demonstrate that public land ranchers are willing to pay more than the current grazing fee to graze public lands.

There seems to be general agreement that, to discover allotment-specific forage values, we must either establish a market for public land grazing through privatization of public lands or by determining lease prices with a competitive bid system. A competitive bid system has strong theoretical appeal, and it has been proposed and studied numerous times in the past (Nielsen 1972, Martin and Jeffries 1966, USDI/USDA 1977, USDA/USDI 1992). However, the option of moving to a competitive bid system has been repeatedly rejected by the federal land agencies. They believe it would be disruptive to the stability of permittees and rural communities
APPENDIX A

Indices used to compute PRIA grazing fees

\begin{tabular}{|c|c|c|c|c|c|c|}
\hline $\begin{array}{r}\text { Reporting } \\
\text { Year } \\
\end{array}$ & Fee Year & FVIAUM $^{*}$ & FVIHEAD" & FVIPRIA ${ }^{2}$ & BCPI & PPI \\
\hline 1964 & 1965 & 96 & & 96 & 87 & 95 \\
\hline 1965 & 1966 & 98 & & 98 & 94 & 97 \\
\hline 1966 & 1967 & 102 & & 102 & 104 & 99 \\
\hline 1967 & 1968 & 102 & & 102 & 105 & 103 \\
\hline 1968 & 1969 & 102 & & 102 & 109 & 107 \\
\hline 1969 & 1970 & 105 & & 105 & 123 & 113 \\
\hline 1970 & 1971 & 111 & & 111 & 134 & 118 \\
\hline 1971 & 1972 & 111 & & 111 & 134 & 124 \\
\hline 1972 & 1973 & 114 & & 114 & 167 & 130 \\
\hline 1973 & 1974 & 125 & & 125 & 195 & 140 \\
\hline 1974 & 1975 & 159 & & 159 & 178 & 168 \\
\hline 1975 & 1976 & 158 & & 158 & 160 & 198 \\
\hline 1976 & 1977 & 175 & & 175 & 164 & 215 \\
\hline 1977 & 1978 & 193 & & 193 & 163 & 230 \\
\hline 1978 & 1979 & 195 & & 195 & 216 & 246 \\
\hline 1979 & 1980 & 206 & 200 & 206 & 294 & 275 \\
\hline 1980 & 1981 & 216 & 233 & 216 & 291 & 319 \\
\hline 1981 & 1982 & 242 & 241 & 242 & 268 & 359 \\
\hline 1982 & 1983 & 229 & 248 & 229 & 262 & 378 \\
\hline 1983 & 1984 & 242 & 236 & 242 & 256 & 387 \\
\hline 1984 & 1985 & 243 & 242 & 243 & 262 & 395 \\
\hline 1985 & 1986 & 230 & 251 & 251 & 243 & 397 \\
\hline 1986 & 1987 & 222 & 233 & 233 & 235 & 388 \\
\hline 1987 & 1988 & 207 & 234 & 234 & 272 & 381 \\
\hline 1988 & 1989 & 233 & 240 & 240 & 297 & 386 \\
\hline 1989 & 1990 & 238 & 243 & 243 & 306 & 402 \\
\hline 1990 & 1991 & 252 & 253 & 253 & 326 & 419 \\
\hline 1991 & 1992 & 253 & 265 & 265 & 327 & 436 \\
\hline 1992 & 1993 & 266 & 275 & 275 & 316 & 440 \\
\hline 1993 & 1994 & 258 & 279 & 279 & 333 & 451 \\
\hline 1994 & 1995 & 274 & 282 & 282 & 304 & 455 \\
\hline 1995 & 1996 & 282 & 301 & 301 & 277 & 473 \\
\hline 1996 & 1997 & 285 & 293 & 293 & 252 & 499 \\
\hline 1997 & 1998 & 293 & 310 & 310 & 281 & 512 \\
\hline 1998 & 1999 & 304 & 323 & 323 & 323 & 272 \\
\hline 1999 & 2000 & 312 & 326 & 326 & 326 & 281 \\
\hline 2000 & 2001 & 318 & 329 & 329 & 329 & 313 \\
\hline 2001 & 2002 & 337 & 345 & 345 & 345 & 330 \\
\hline
\end{tabular}

Source: USDAVUSDI (1992, p. 18) and updated values reported in USDA-NASS Agricultural Prices (Various Issues).

"/The PRIA fee formula expired with the 1986 fee year, and Executive Order 12548 mandated that the FVI be defined as the per head per month rate for pasturing cattle on private rangelands in the 11 western states. This was a redefinition relative to the per AUM definition previously used. The FVIPRIA column includes this redefinition, beginning with the 1986 fee year. 
dependent upon public land forage, and would not be manageable given the isolated and scattered nature of many public lands grazing permits, especially with current permit structure, regulation, and staffing (USDI/USDA 1977, p. 7-7, USDA/USDI 1992, p. 40, USDI/USDA 1993 , p. 15). No effort has been undertaken to seriously evaluate the feasibility of moving to a competitive bid system on public lands. As noted by the land agencies, scattered and isolated allotments create obstacles for having multiple and competitive bids submitted under an open eligibility bidding system. But, in many cases, market-driven competitive bids and lease rates could be obtained. Average bid rates for selected areas or grazing districts could then be used to set fees for tracts for which a competitive bid was not possible.

Competitive bidding on lands administered by BLM has occurred on a very limited basis on the McGregor Bombing Range in southern New Mexico and at Fort Meade in South Dakota (USDA/USDI 1992, Fowler et al. 1994). Competitive bids are also allowed on state trust lands in many western states (Baldwin and Cody 1996). These leases have recently been controversial as environmental groups have offered bids in an attempt to preclude grazing on state lands. The question of bidding procedure and qualified bidders are details that would have to be addressed prior to instituting an expanded bidding system for public lands. Perhaps more important is the question of whether a competitive bidding process would be politically possible, socially acceptable and economically justified. As noted by McCarl and Brokken (1985, p. 777 ), the desirability of moving to a competitive bid system will ultimately depend on transaction and administrative costs that will occur under a bidding program. Other key issues include the desire for simplicity, the feasibility and need to alter current rules and regulations to open and expand the number of eligible bidders, and equity concerns about who gains and loses as grazing policies change. McCarl and Brokken (1985) expressed a concern that the data needed to implement a competitive bid system will not be forthcoming and question whether its social value would be worth the costs incurred in its development. While recognizing the potential validity of these concerns, and those of the land agencies, we believe the competitive bid option warrants additional study and serious consideration.

If McCarl and Brokken (1985, p. 777) are correct such that we must settle for a somewhat arbitrary institutionalized system for setting grazing fees, the Public Rangeland Improvement Act (PRIA) evaluation presented here has several clear implications for the development of a new fee system. Clearly, the Beef Cattle Price Index (BCPI) and Prices Paid Index (PPI) should be discarded when judged against the criteria of preventing future discrepancies in grazing fees. Van Tassell and McNeley (1997) have documented that beef prices and production costs are adequately captured in the Forage Value Index (FVI), as economists argued was the case when decisions were originally made to include the BCPI and PPI in the PRIA fee formula. Further, as demonstrated by McCarl and Brokken (1985) and this update, adding these 2 indices did not improve the tracking ability of the PRIA fee formula as was originally envisioned, and, in fact, had exactly the opposite effect.

Perhaps the best estimate of what private forage will lease for next year is what it leased for this year. The lagged FVI has proven to track private land lease rates through time (Fig. 1). It likely does not matter whether per AUM or per head rates are used in defining the FVI and there is always room to improve the lease rate data collection process and expand sample size. The weighting of the lagged FVI could be one (1), but an improved tracking could be obtained by recognizing that nominal forage values are expected to grow over time. Efficient pricing of public forage on a sitespecific basis will be more complicated and may require data collection and administrative costs that would not be justified from grazing values.

\section{Literature Cited}

Arthur D. Little, Inc. 1967. An analysis of western livestock grazing costs. A report to USDI. Rep. No. 69463.

Arthur D. Little, Inc. 1968. A multivariate analysis of livestock grazing costs. A report to USDI Rep. No. 69781.

Backiel, A. and L.A. Rogge. 1985. Federal grazing fees on lands administered by the Bureau of Land Management and the Forest Service: a history of legislation and administrative policies. 85-592 ENR. Congressional Research Service, The Library of Congress. A report prepared at the request of the Committee on Appropriations, Subcommittee on Interior, U.S. House of Representatives. Washington, D.C.

Baldwin, P. and B. Cody. 1996. Survey of grazing programs in western states. Congressional Research Service (CRS) report 96-97A. Available online at
http://www.ncseonline.org/NLE/CRSreports/ Agriculture/ag-12.cfm. (site last accessed 14 Feb. 2003).

Bartlett, E.T., L.A. Torell, N.R. Rimbey, L.W. VanTassell, and D.W. McCollum. 2002. Valuing grazing use on public land. J. Range Manage. 55:426-438.

Bartlett, E.T., N. Rimbey, L.A. Torell, L.W. Van Tassell, J. Devilbiss, R. Appel, T. Heisler, G. Stoebig, T. Bagwell, P. Burgener, and J. Coen. 1993. The Federal Grazing Fee: 1993, Part I. pp. 1-146. In: USDI-BLM/USDA-USFS, Incentive-based grazing fee system for public rangeland administered by the Bureau of Land Management and U.S. Forest Service, Washington, D.C.

Brokken, R.F. and B.A. McCarl. 1987. A theoretical evaluation of fee systems for private grazing on federal lands. USDA-Economic Research Service (ERS) Rept. No. 570. Washington, D.C.

Dutton, W.L. 1953. History of Forest Service grazing fees. J. Range Manage. 6:393-398.

Freund, R.J. and R.C. Littell. 1991. SAS system for regression, $2^{\text {nd }}$ edition. SAS Inst., Inc. Cary, N.C.

Fowler, J.M., L.A. Torell, and G. Gallacher. 1994. Competitive pricing for the McGregor Range: implications for federal grazing fees. J. Range Manage. 47:155-158.

Gardner, B.D. 1963. A proposal to reduce misallocation of livestock grazing permits. J. Farm Econ. 45:109-120.

Gardner, B.D. 1983. Market versus political allocations of natural resources in the 1980s. West. J. Agr. Econ. 8:215-229.

Gardner, B.D. 1989. A proposal for reallocation of federal grazing-revisited. Rangelands 11:107-111.

Gardner, B.D. 1997. The political economy of public land use. J. Agr. and Res. Econ. 22:12-29.

Greene, W.H. 1993. Econometric analysis. MacMillan Publishing Co., New York, N.Y. Second Ed.

Kearl, G.W. 1989. Critical review of federal grazing fee studies. Univ. of Wyoming. Agr. Exp. Sta. Report B-930. Laramie, Wyo.

LaFrance, J.T. and M.J. Watts. 1995. Public grazing in the West and "Rangeland Reform '94”. Amer. J. Agr. Econ. 77:447-461.

Martin, W.E. and G.L. Jefferies. 1966. Relating ranch prices and grazing permit values to ranch productivity. J. Farm Econ. 48:233-242

McCarl, B.A. and R.F. Brokken. 1985. An economic analysis of alternative grazing fee systems. Amer. J. Agr. Econ. 67:769-778.

Nielsen, D.B. 1972. Economic implications of variable versus single grazing fees. J. Range Manage. 25:2-5.

Pope, C.A. and H.L. Goodwin. 1984. Impacts of consumptive demand on rural land values. Amer. J. Agr. Econ. 66:750-754.

Rachford, C.E. 1924. Range appraisal report. Unpublished report prepared for the Secretary of Agriculture, USDA Forest Serv., Washington, D.C. Nov. 5. 
Rimbey, N.R. 1990. Idaho state land grazing fee issues. Progress report presented to State of Idaho Land Board subcommittee on grazing fees, July 30 , Boise, Ida.

Tittman, P.T. and C.E. Brownell. 1984. Appraisal report estimating fair market value of grazing on public lands. Prepared for USDA Forest Service and USDI Bureau of Land Management. Washington, D.C.

Torell, L.A. and S.A. Bailey. 2000. Is the profit motive an important determinant of grazing land use and rancher motive. Selected Paper Western Agr. Econ. Assoc. Annual Meeting, Vancouver, B.C., June 29-July 1, 2000. Agr. Econ. Research: Research in Agr. and Applied Econ. Available online at http://agecon.lib.umn.edu/. (site last access 14 Feb. 2003).

Torell, L.A., S. Ghosh, and J.M. Fowler. 1989. Economic considerations for setting grazing fees on New Mexico state trust lands. New Mexico State Univ. Agr. Exp. Sta. Spec. Rep. 81. Las Cruces, N.M.

Torell, L.A., N.R. Rimbey, J.A. Tanaka, and S.A. Bailey. 2001. The lack of a profit motive for ranching: implications for policy analysis. In: L.A. Torell, E.T. Bartlett, and R. Larranaga (eds. Current issues in rangeland resource economics: Proc. of a symposium sponsored by Western Coordinating Committee 55 (WCC-55), N.M. State Univ., Res. Rep. 737, Las Cruces, N.M. Available online at http://agecon.lib.umn.edu/. (site last accessed 14 Feb. 2003).
U. S. Department of Agriculture, Forest Service and U. S. Department of Interior, Bureau of Land Management (USDA/USDI). 1986. Grazing fee review and evaluation final report 1979-1985. A report from the Secretaries of Agr. and Interior. Washington, D.C.

U. S. Department of Agriculture, Forest Service and U. S. Department of Interior, Bureau of Land Management (USDA/USDI). 1992. Grazing fee review and evaluation update of the 1986 final report. A report from the Secretaries of Agriculture and Interior. Washington, D.C.

U.S. Department of Agriculture, National Agricultural Statistics Service (USDANASS). Various Issues. Agricultural prices. Washington D.C. Available online at http://usda.mannlib.cornell.edu/reports/nassr/pr ice/pap-bb/. (site last accessed 14 Feb. 2003).

U. S. Department of Interior, Bureau of Land Management and U. S. Department of Agriculture, Forest Service (USDI/USDA). 1977. Study of fees for grazing livestock on federal lands. A report from the Interior and Agr. Washington, D.C.

U. S. Department of Interior, Bureau of Land Management and U. S. Department of Agriculture, Forest Service (USDI/USDA). 1993. Incentive-based grazing fee system for public rangeland administered by the Bureau of Land Management and U.S. Forest Service. A report from the Secretaries of Interior and Agriculture. Washington, D.C.
U.S. Department of Interior, Bureau of Land Management in cooperation with $U$. S. Department of Agriculture, Forest Service (USDI/USDA). 1994. Rangeland Reform '94: Draft Environmental Impact Statement. Washington, D.C.

U.S. Department of Interior, Bureau of Land Management and U. S. Department of Agriculture, Forest Service (USDI/USDA). 1995. Rangeland Reform ' 94 : Final Environmental Impact Statement. Washington, D.C.

Van Tassell, L.W. and S.M. McNeley. 1997. Factors affecting private rangeland lease rates. J. Range Manage. 50:178-184.

Whittlesey, N.K., R.G. Huffaker, and W.R. Butcher. 1993. Grazing policy on public lands. Choices. Third Quarter 15-19.

Workman, J.P. 1988. Federal grazing fees: a controversy that won't go away. Rangelands. $10: 128-130$ 